GU J Sci, Part C, 7(4): 999-1011 (2019)

Gazi Üniversitesi
Fen Bilimleri Dergisi
PART C: TASARIM VE TEKNOLOJI
http://dergipark.gov.tr/gujsc

Numerical Analysis of Two Units PEM Fuel Cell Stack

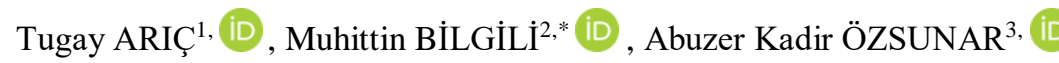 \\ ${ }^{1,2,3}$ Gazi University, Faculty of Engineering, Department of Mechanical Engineering, 06570, Maltepe/ANKARA
}

\section{Article Info:}

Research article

Received: 24/09/2019

Revision 19/11/2019

Accepted: $27 / 11 / 2019$

\section{Highlights}

- PEMFC stack modelling

- Electrical power curve

- CFD analysis of fuel cell

\section{Keywords}

\section{PEM Fuel Cell}

Bipolar Plate

Fuel Cell Stack

\section{Graphical/Tabular Abstract}

In this study, PEM fuel cell stack is analyzed by numerically. By using the same cell dimensions, electrochemical and physical properties at each layer of the cell, a PEM fuel cell stack is designed and prepared. Each cell has $5.4 \mathrm{~cm}^{2}$ active area and connected in series. Reactants of anode and cathode flow direction is preferred parallel. PEM fuel cells are accepted as operating conditions of $70^{\circ} \mathrm{C}$ and $1 \mathrm{~atm}$. Polarization curves and electrical power curves are obtained for different current densities values of single and stack of PEMFC.

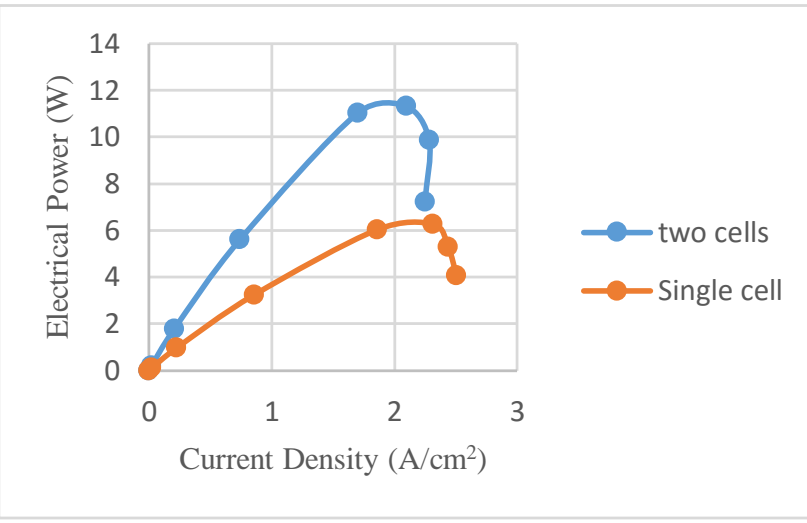

Figure A. Electrical power curves corresponding to current density for single and two cells

Purpose: In this study, single and two unit PEM fuel cell stack are analyzed numerically and electrical power values calculated. Thereby it is observed that number of fuel cell units effects on the electrical power. It is also obtained how effectively increasing electrical power for two different number of fuel cell unit.

Theory and Methods: In this study, PEMFC single cell and stack models has been designed by CATIA V5R21. These designed cell models were analyzed for single and stack cell using ANSYS FLUENT.

Results: The maximum electrical power values obtained from two cells stack and single cell were calculated as $11.32 \mathrm{~W}$ and $6.26 \mathrm{~W}$, respectively. It is observed when the number of units in the PEMFC is increased, it is attained more electrical power nearly at the same range. Reasons of the losses in the electrical power are estimated as friction, ohmic losses or rising of fluid cover distance.

Conclusion: Design and analysis of one and two units PEMFC are investigated in this study. And it has been observed when the cell number is increased from one to two cells, electrical power is increased about the same amount. Moreover, the distribution of reactants in the channels, temperature distributions, current density distributions and water saturation at selected cross sectional area for a two units fuel cell stack is analyzed at the different voltage values. 
GU J Sci, Part C, 7(4): 999-1011 (2019)

Gazi Üniversitesi
Fen Bilimleri Dergisi
PART C: TASARIM VE TEKNOLOJI
http://dergipark.gov.tr/gujsc

\title{
İki Hücreli PEM Yakıt Pili Yığının Sayısal Analizi
}

\author{
Tugay ARIÇ, (iD), Muhittin BİLGİLì'², (iD , Abuzer Kadir ÖZSUNAR ${ }^{3}$, \\ ${ }^{1,2,3}$ Gazi University, Faculty of Engineering, Department of Mechanical Engineering, 06570, Maltepe/ANKARA
}

\section{Makale Bilgisi \\ Araştırma makalesi \\ Başvuru: 24/09/2019 \\ Düzeltme: 19/11/2019 \\ Kabul: 27/11/2019}

\section{Anahtar Kelimeler}

PEM Yakıt Pili

Bipolar Plaka

Yakıt Pili Yı̆̆ı̆ı

\begin{abstract}
$\ddot{O} \mathbf{z}$
İnsanoğlunun enerji ihtiyacının büyük bir kısmını karşılayan petrol, doğalgaz gibi fosil enerji kaynaklarının gün geçtikçe azalmakta ve enerji üretiminde kullanılan kaynakların çevreye verdiği zararın giderek artması bilim adamlarını alternatif enerji kaynaklarına yönlendirmektedir. $\mathrm{Bu}$ alternatif enerji kaynaklarından biri olan yakıt pili uygulaması dikkatleri üzerine çekmektedir. Bu çalışmada iki hücreli bir PEM yakıt pili yığının analizi sayısal olarak yapılmıştır. Çalışmada her biri $5.4 \mathrm{~cm}^{2}$ 'lik aktif alana sahip iki PEM yakıt hücresi seri olarak bağlanarak yığın haline getirilmiştir. Anot ve katot bölümlerindeki reaktantların akış yönü paralel olarak tercih edilmiştir. Analiz edilen PEM yakıt pilinin çalışma koşulları ise $70^{\circ} \mathrm{C}$ ve 1 atm olarak belirlenmiştir. $\mathrm{Bu}$ tasarlanan yığından elde edilen güç değerleri hesaplanarak çalışmada sunulmuştur. Tek hücreli yakıt pili ve iki hücreli yığından elde edilen elektriksel güç değerleri grafikler halinde gösterilmiştir.
\end{abstract}

Keywords

PEM Fuel Cell

Bipolar Plate

Fuel Cell Stack

\section{Numerical Analysis of Two Units PEM Fuel Cell Stack}

\begin{abstract}
The fact that the industrial factor progresses to the point where the fossil energy sources such as petroleum natural gas, which constitute a large part of human's energy needs, move to the point of decreasing and exhausting day by day, and the increasing damage caused by the resources used for energy production leads the scientists to alternative energy sources. Fuel oil application, one of these alternative energy sources, draws attention. In this study, PEM fuel cell stack is analyzed by numerically. Two PEM fuel cells are turned into stack, each of which has $5.4 \mathrm{~cm}^{2}$ active area, by connecting in series. Reactants of anode and cathode flow direction is preferred parallel. PEM fuel cells are accepted as operating conditions of $70^{\circ} \mathrm{C}$ and $1 \mathrm{~atm}$. Power values of this designed stack is calculated and presented in the study. Electrical power values of one and two PEMFCs are presented in graphics.
\end{abstract}

\section{GIRIŞ (INTRODUCTION)}

Son yıllarda fosil enerji kaynaklarının yol açtığı problemler nedeniyle dünyada yenilenebilir enerji konusu üzerine gittikçe artan bir ilgi vardır. Yenilenebilir enerji kaynaklarından güneş, rüzgar gibi sürekliliğgi olmayan alternatif enerji kaynaklarının kullanımında enerjinin depolanması ihtiyacı hidrojen enerjisinin kullanımını gündeme getirmiştir.

Hidrojen enerjisi konusundaki araştırmaların en ağırlıkı kısmını yakıt pilleri oluşturmaktadır. Yakıt pilleri yüksek verim, yan ürün olarak su çıkarması ve sessiz çalışması gibi avantajlara sahiptir. Yakıt pilleri; güç santralleri, otomobiller, dizüstü bilgisayarlar, cep telefonları gibi farklı ölçekte güç gerektiren yerlerde kullanılabilir. Yakıt pilleri içerisinde düşük sıcaklıklarda çalışmaları ve yüksek verimleri sebebiyle en çok ilgiyi çekenlerden biri PEM yakıt pilleridir. PEM yakıt pillerinin yoğun kullanılmasının sebeplerinden bazıları ise yüksek enerji yoğunluğu ve yüksek çalışma süresine sahip olması, hızlı şarj edilebilirliği ve çevre dostu olmasıdır [1,15]. 
Çalışmanın konusu olan 2 hücreli yığın tasarımında hücre sayısını arttırarak elde edilecek gücü de artırmaktır. Deneysel çalışmalardan görülmektedir ki hücre sayısıyla elde edilen güç de doğru oranda artmaktadir [2].

Bir yığın tasarımında verimliliği etkileyen birçok faktör vardır. Bunlardan başlıcaları reaktantların giriş debileri, sıcaklık basınç değerleri ve akış kanalı geometrisidir. Bu yüzden yakıt pili verimliliğini arttırmaya yönelik çoğu çalışma bu konular üzerinden ilerlemektedir. PEM yakıt pillerinde en önemli problemlerden biri akış kanal deseninin doğru tasarımıdır. Bu yüzden çoğu çalışma akış kanalı tasarımı üzerine yoğunlaşmaktadır. Bu tasarımlar yapılırken amaç basınç düşüşünü engelleyip uniform bir akış sağlayıp verimliliği artırmaktır [3].

$\mathrm{Bu}$ doğrultuda bipolar plaka kesiti genellikle dikdörtgen olsa da, yarı çembersel, üçgen vb. biçimlerinde kesit alanına sahip çeşitli plakalar da çalışmalarda kullanılmıştır [4].

Bunların yanında deneysel olarak bakıldığında yakıt pili performansını etkileyen başka etmenler de ortaya çıkmaktadır.

Bipolar plakalar PEM yakıt pili performansında kritik bir etkiye sahiptirler. Bir gaz sızıntısı veya reaksiyon sırasında üretilen suyun kötü yönetimi yığının bozulmasına neden olmaktadır. Farklı çalışma koşullarında bipolar plaka akış kanalı geometrisini değiştirerek akış kanallarında en iyi hız ve reaktant dağılımı elde edilmelidir [5].

Yakıt pillerinde bipolar plakanın bir yüzeyi hücrenin anot tabakası iken diğer taraf katot katmanıdır. Her iki yüzey yakıt ve oksidant için akış kanallarına sahiptir. Bu kanallar sayesinde yakıt ve oksidant aktif alanda eşit olarak dağıtılmaya çalış1ır. Bu homojen dağılım hücre performansını ve verimini arttırır. Bipolar plakalar, oksijenin ve yakıtın aktif bölgelere dağılımını sağlamakla, ısının aktif alanlardan uzaklaştırılmasıyla, hücreden hücreye akımın iletilmesiyle ve reaktantların yakıt pili sistemindeki sızıntısının önlenmesinden sorumludur [6].

Bipolar plakanın yüzeyinde reaktant gazların yakıt pili içerisinde dağıtımı için gaz akış kanalları vardır. Kanal geometrisi, kullanılan kanal deseni anot ve katot tarafı için farklı olabilir. Ayrıca reaktantların yakıt pili sisteminde akış yönü isteğe göre eş veya zıt olabilir. Bipolar plaka gaz akış kanalı deseninin seçimi ve optimizasyonu, yakıt pilinin performansını büyük ölçüde etkiler. Temel geometri seçimine ek olarak, kanallar arasındaki kanal boyutları ve akış kanal deseni dikkatle düşünülmelidir. Aksi takdirde, rastgele seçimler beklenen hücre akımının ve performansı değerlerine ulaşmayı engeller [7].

Teorik açıdan bakıldığında yakıt pilinde gerçekleşen kimyasal reaksiyon sonucu elde edilen elektriksel potansiyel 1.23 V'tur. Ancak deneysel çalışmalarda bu değer 1 V'un altına düşebilmektedir. Eğer tek bir pilin $1 \mathrm{~kW}$ güç üretmesi bekleniyorsa bunu tek bir hücreyle elde etmek mümkün değildir. Bunun için çok sayıda hücreden oluşan bir yığın yakıt pili kullanılmalıdır. Hücre sayısı arttıkça yığın voltajı da doğru orantılı olarak artacağından yakıt pilinden sağlanacak güç de artacaktır [8].

Bu çalışmada iki hücreli bir yakıt pili tasarlayıp tek hücreli yakıt piline göre elde edilen elektriksel güç miktarları karşılaştırılmıştır. Ayrıca 2 hücreli yakıt pili için voltaj değerine karşılık gelen akım yoğunluğunu gösteren bir polarizasyon eğrisi elde edilmiştir. Bu çalışmayla yakıt pili hücre sayısının elde edilen elektriksel güce etkisinin incelenmiştir. Ayrıca hücre sayısı arttıkça meydana gelen kayıplarda yapılan analiz sonucunda irdelenmiştir.

\section{SAYISAL YÖNTEM (NUMERICAL METHOD)}

\subsection{Yakıt Pili Tasarımı (Design of Fuel Cell)}

Bir yakıt pilinden elde edilecek elektriksel gücü arttırmanın çeşitli yolları vardır. Bunlardan biri yüzey aktif alanın miktarını arttırmaktır. Ancak bu yöntem çok kullanışsız ve verimsiz bir yöntem olacaktır. Bu yüzden elde edilen gücü arttırmak için kullanılabilecek en akıllıca yöntem yakıt pilindeki hücre sayısını arttırmak olacaktır [8]. 
Hücre sayısını arttırmak elde edilecek elektriksel gücü arttıracaktır. Ancak artan hücre sayısıyla beraber yakıt pili performansında da düşüşler olacaktır ve elde edilen akım yoğunlukları arasında farklar olacaktır. Bu farkların en büyüğü ise tek hücreli ve iki hücreli yakıt pilleri arasındaki farktır. \% 23,4 olan bu fark devam eden hücre artışlarında giderek azalmaktadır [9].

Bu çalışmada 2 hücreli bir PEM yakıt pili tasarımı yapılarak, tek hücreli yakıt piline göre elde edilen gücün artışı ANSYS FLUENT programı ile analiz edilmiştir. Buradan elde edilen verilerle hücre sayısındaki artışa bağlı olarak meydana gelebilecek kayıplar görülüp, 2 hücreli bir PEM yakıt pili için bir polarizasyon eğrisi elde edilmiştir. Analizde kullanılan tasarım ve ölçüleri Şekil 1 ve Tablo 1 olarak gösterilmiştir.

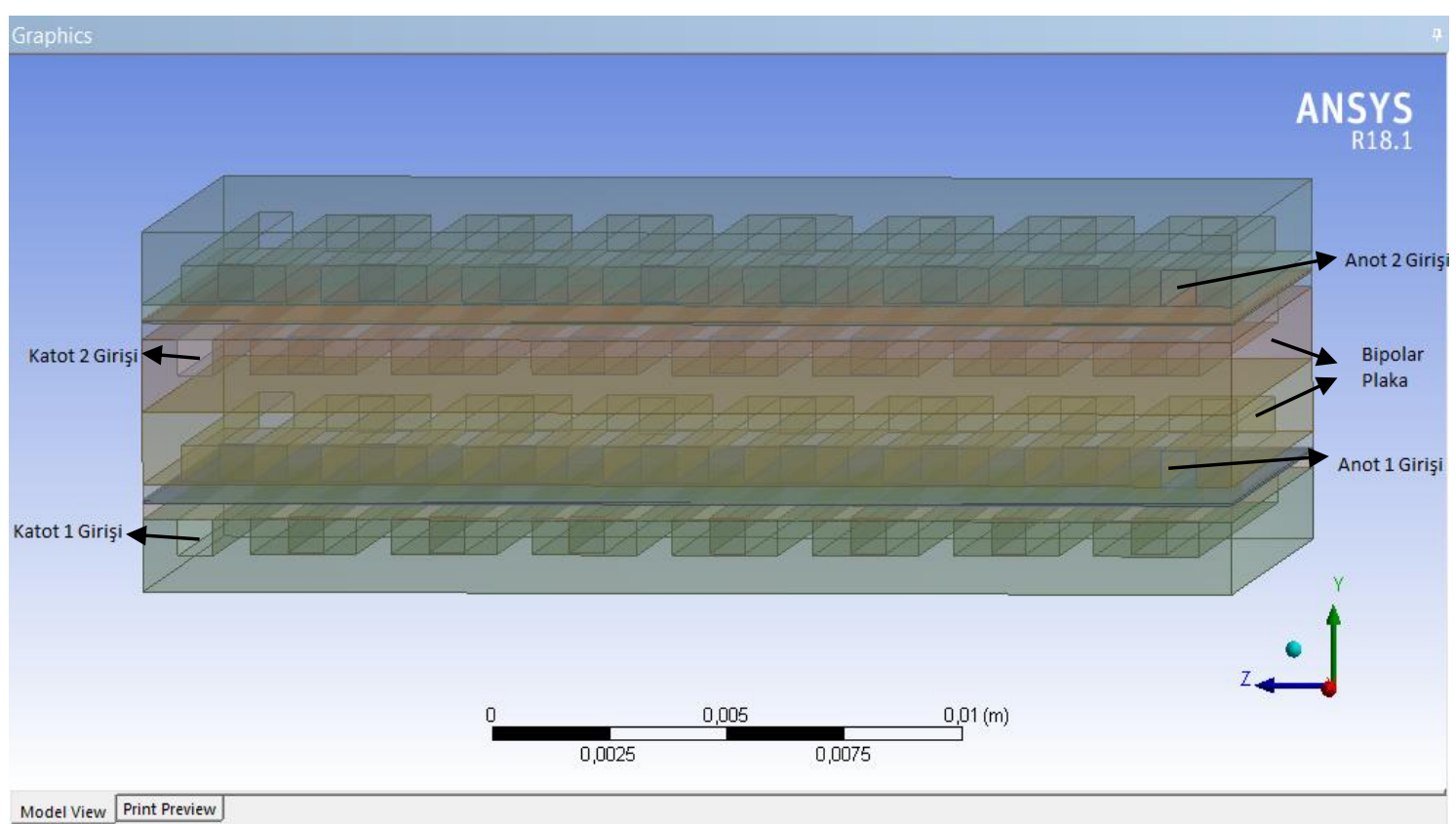

Şekil 1. İki hücreli PEM yakıt pili geometrisi

Tablo 1. PEM yakıt hücresinin geometrik ölçüleri

\begin{tabular}{|l|l|l|}
\hline FiziKSEL BOYUTLAR & 1S SERPANTiN & BiRiM \\
\hline Kanal derinliği & 0.75 & $\mathrm{~mm}$ \\
\hline Kanal genişliği & 0.75 & $\mathrm{~mm}$ \\
\hline Akış kanalı kesit alanı & $0.5625 \mathrm{e}-06$ & $\mathrm{~m}^{2}$ \\
\hline Yakıt pili aktif alanı & 0.00054 & $\mathrm{~m}^{2}$ \\
\hline $\begin{array}{l}\text { Difüzyon tabakası } \\
\text { kalınlığı }\end{array}$ & 0.325 & $\mathrm{~mm}$ \\
\hline $\begin{array}{l}\text { Katalizör tabakası } \\
\text { kalınlığı }\end{array}$ & 0.015 & $\mathrm{~mm}$ \\
\hline Membran Kalınlığı & 0.05 & $\mathrm{~mm}$ \\
\hline
\end{tabular}

Tasarlanan bu yakıt pilinin mesh işlemi, mesh kalitesinin yüksek ve analizin hassas olması amacıyla ICEM üzerinden yapılmıştır. 


\subsection{Yakıt Pili Yığın Hesaplamaları (Calculations of Fuel Cell Stack)}

PEM yakıt pilindeki güç hesaplamaları temel olarak yakıt pili voltaj değerine ve akım yoğunluğu değerine bağlıdır. Bir yakıt pilinden elde edilebilecek güç basit olarak:

$$
\mathrm{W}=\mathrm{V}_{\mathrm{y} \mathrm{g} \breve{m}} \mathrm{x} \mathrm{I}
$$

$\mathrm{V}_{\text {yığın }}$ değeri yığının voltaj değeri olup, her bir hücredeki ortalama voltaj değerinin yakıt pilindeki hücre sayısıyla çarpılması sonucu elde edilir.

$$
\mathrm{V}_{\text {yı̆̆ın }}=\mathrm{V}_{\text {hücre }} \mathrm{X} \quad \mathrm{N}_{\text {hücre }}
$$

Akım (I) ise, elde edilen akım yoğunluğu (i) $\left[\mathrm{A} / \mathrm{cm}^{2}\right]$ değerinin tasarımdaki yakıt pili aktif yüzey alanının çarpılması sonucu elde edilir. PEM yakıt pillerinde yakıt pili performansını dolayısıyla elde edilecek akım yoğunluğu ve güç değerlerini etkileyen en önemli faktörler reaktant debisi, çalışma basınç ve sıcaklık değerleri ve stokiyometri oranlarıdır. Çalışmada analizler $70^{\circ} \mathrm{C}$ sıcaklık ve $1 \mathrm{~atm}$ basınç değerleri için gerçekleştirilmiştir. Bu çalışma sıcaklık ve basınç değerleri için yakıt piline gönderilecek olan reaktant gazların kütle debileri aşağıdaki eşitlikler kullanılarak hesaplanmıştır.

$$
\mathrm{U}_{\mathrm{a}, \text { in }}=\zeta \mathrm{a} \frac{I}{n_{e} F} \text { Amea } \frac{1}{X_{H 2}} \frac{R T_{\text {in }}}{P_{\text {in }}} \frac{1}{A_{c h}}
$$

Eş.(3)'deki $\zeta$ reaktant gazların stokiyometri oranı, ne reaktantların bir molünde bulunan elektron sayısını, $\mathrm{A}_{\text {mea }}$ aktif alan $\left(\mathrm{m}^{2}\right), \mathrm{A}_{\mathrm{ch}}$ kanal kesit alanı $\left(\mathrm{m}^{2}\right)$, X reaktant gazların mol oranı, I : Anot ve katot tarafları için referans akım yoğunlukları $\left(\mathrm{A}^{*} \mathrm{~m}^{-2}\right), \mathrm{F}($ Faraday sabiti $)=96485$ Coulombus/electron-mol, $\mathrm{R}=8.314 \mathrm{~kJ} / \mathrm{kg} . \mathrm{K}$, $\mathrm{T}_{\text {in }}$ giriş sıcaklığ $70^{\circ} \mathrm{C}(343.343 \mathrm{~K}), \zeta_{\mathrm{a}}=2.5, X_{H 2}=0.794038$ ve anot akım referans yoğunluğu $\mathrm{I}=10000$ $\mathrm{A} / \mathrm{m}^{2}$ olarak hesaba katılmıştır.

Buradan hacimsel debi ve nem oranları:

$$
\begin{gathered}
\dot{V}_{\mathrm{a}, \mathrm{in}}=\mathrm{U}_{\mathrm{a}, \mathrm{in}} * \mathrm{~A}_{\mathrm{ch}, \mathrm{in}} \\
\mathrm{W}_{\mathrm{an}}=\frac{P_{H 2 O} * V / T * R_{\mathrm{H} 2 \mathrm{O}}}{V * P_{H 2} / R_{T}}=\frac{R_{\mathrm{H} 2}}{R_{\mathrm{H} 2 \mathrm{O}}} \frac{P_{\mathrm{H} 2 \mathrm{O}}}{P_{H 2}}=8.936 \frac{P_{\mathrm{H} 2 \mathrm{O}}}{P-P_{\mathrm{H} 2 \mathrm{O}}}
\end{gathered}
$$

Bu hesaplamaların ardından kütle debisi:

$$
\dot{m}_{a n}=U_{a n, i n} / \mathrm{V}_{\text {an }}
$$

$\mathrm{Bu}$ hesaplamalar anot tarafı için yapılmış ve aynı şekilde katot kısmı için tekrarlanmıştır. Yapılan bu hesaplamalar doğrultusunda anot tarafi için giriş debisi $1.988 \mathrm{e}-07 \mathrm{~kg} / \mathrm{s}$ ve katot tarafı için giriş kütle debisi ise $8.342 \mathrm{e}-06 \mathrm{~kg} / \mathrm{s}$ olarak bulunmuş ve analizler bu değerlere göre yapılmıştır.

Tablo 2. Reaktantların fiziksel özellikleri

\begin{tabular}{|l|l|l|l|}
\hline Fiziksel Özellik & $\mathbf{H}_{2}$ & $\mathbf{O}_{2}$ & $\mathbf{H}_{2} \mathbf{O}$ (su buharı) \\
\hline Özgül Isı $\left(\mathrm{Jg}^{-1} \mathrm{~K}^{-1}\right)$ & 14283 & 919.31 & 2014 \\
\hline Isıl İletim Katsayısı $\left(\mathrm{W} \mathrm{m}^{-1} \mathrm{~K}^{-1}\right)$ & 0.1672 & 0.0246 & 0.0261 \\
\hline Viskozite $\left(\mathrm{kg} \mathrm{m}^{-1} \mathrm{~s}^{-1}\right)$ & $8.41 \times 10^{-6}$ & $1.91 \times 10^{-5}$ & $1.34 \times 10^{-5}$ \\
\hline Molekül Ağırlığı $\left(\mathrm{kg} \mathrm{kmol}^{-1}\right)$ & 2.01594 & 31.9988 & 18.01534 \\
\hline Elektrik İletkenliği $(\mathrm{Ohm} \mathrm{m})^{-1}$ & $1 \times 10^{-16}$ & $1 \times 10^{-16}$ & $1 \times 10^{-16}$ \\
\hline
\end{tabular}


Tablo 3. Sayısal analizde kullanilan elektrokimyasal parametreler

\begin{tabular}{|c|c|c|}
\hline PARAMETRELER & DEĞER & BíRiM \\
\hline Anot Referansı Akım Yoğunluğu & 10000 & A.m- $\mathrm{m}^{-2}$ \\
\hline Anot Referansı Mol Derişimi & 1 & $\mathrm{kmol} . \mathrm{m}^{-3}$ \\
\hline Anot Derişiminin Değeri & 0.5 & - \\
\hline Anot Aktarım Katsayısı & 1 & - \\
\hline Katot Referansı Akım Yoğunluğu & 20 & A. $\mathrm{m}^{-2}$ \\
\hline Katot Referansı Mol Derişimi & 1 & $\mathrm{kmol} . \mathrm{m}^{-3}$ \\
\hline Katot Derişiminin Değeri & 1 & - \\
\hline Katot Aktarım Katsayısı & 1 & - \\
\hline Açık Devre Voltajı & 0.98 & $\mathrm{~V}$ \\
\hline GDL Isıl İletkenliği & 1.6 & $\mathrm{~W}(\mathrm{~m} \cdot \mathrm{K})^{-1}$ \\
\hline Katalizör Tabakası Isıl liletkenliği & 2 & $W(m \cdot K)^{-1}$ \\
\hline Bipolar Plakanın Isıl İletkenliği & 20 & $W(m \cdot K)^{-1}$ \\
\hline GDL Elektriksel İletkenliği & 2500 & (ohm.m) $)^{-1}$ \\
\hline Katalizör Tabakası Elektriksel İletkenliği & 2500 & (ohm.m) $)^{-1}$ \\
\hline Bipolar Plaka Elektriksel İletkenliği & 22000 & (ohm.m) $)^{-1}$ \\
\hline GDL Gözenekliliği & 0.75 & - \\
\hline Katalizör Tabakası Gözenekliliği & 0.5 & - \\
\hline Temas Açısı Anot / Katot & 165 & o \\
\hline Temas Direnci & $5 e-07$ & Ohm.m ${ }^{2}$ \\
\hline Membran Eşdeğer Ağırlık & 1100 & $\mathrm{~kg} \cdot \mathrm{kmol}^{-1}$ \\
\hline
\end{tabular}

Bunlarla beraber ANSYS FLUENT ile sayısal analiz probleminin çözümünde kullanılan denklemler aşağıda verilmiştir. Modelde iki adet faz durumundan söz etmek mümkündür. Bunlar sıvı ve gaz fazlarıdır. Problem iki fazlı olarak çözülmüş̧ür.

Kanallardaki ve gaz difüzyon katmanındaki süreklilik denklemi, kütlenin korunumundan:

$\nabla(\rho \varepsilon u)=S_{m}$

Şeklinde verilmiştir. Bu denklemde $\varepsilon$ elektrottaki gözeneklilik katsayısı, $\rho$ gaz karışımının yoğunluğu ve $u$ akışkanın hız vektörüdür. $S_{m}$, PEM yakıt pilindeki reaktantların elektrokimyasal reaksiyon boyunca üretim ve tüketimlerini göstermektedir.

Momentumun korunumu denklemi,

$\nabla .(\varepsilon \rho \mu u)=-\varepsilon \nabla p+\left(\varepsilon \mu_{e f f} \nabla u\right)+S_{u}$

şeklindedir. Bu denklemde p basınç ve $\mu$ viskoziteyi temsil etmektedir. $S_{u}$ problemdeki gözenekli ortama bağlı kaynak terimidir.

Enerji denklemi ise,

$$
\nabla \cdot\left(\lambda_{e f f} \nabla T\right)=\nabla \cdot\left(\varepsilon \rho C_{p} u T\right)+S_{h}
$$

şeklinde ifade edilir. Burada $\lambda_{\text {eff }}$ efektif 1 sıl iletkenlik, $C_{p}$ izobarik 1sı, $S_{h}$ enerji kaynağı terimidir.

Gaz-sıvı karışımındaki her bir türün konveksiyon, difüzyon, reaksiyon tüketimi için korunum denklemi,

$\frac{\partial\left(\varepsilon C_{k}\right)}{\partial t}+\nabla\left(\varepsilon \vec{u} C_{k}\right)=\nabla\left(D_{k}^{e f f} \nabla C_{k}\right)+S_{k}$

şeklindedir. Burada $S_{k}$ volumetrik kaynak terimi ve $D_{k}^{e f f}$ efektif gaz difüzyon gücünü simgelemektedir.

Bu yakıt pilindeki yükün korunumu denklemi ise elektronlar için,

$\nabla \cdot\left(\sigma_{s}^{e f f} \nabla \Phi_{s}\right)=S_{e}$ 
protonlar için,

$\nabla \cdot\left(\sigma_{m}^{e f f} \nabla \Phi_{m}\right)=S_{i}$

şeklindedir. Bu denklemde $\Phi_{s}$ katı faz potansiyelini, $\Phi_{m}$ membran potansiyelini, $\sigma_{s}^{\text {eff }}$ efektif elektrik iletkenliğini ve $\sigma_{m}^{e f f}$ membranın iyonik iletkenliğini temsil etmektedir.

Butler-Volmer denklemi ise katalizör katmanındaki üretilip iletilen akımı çözmek için kullanılır ve aşağıdaki gibidir:

$\mathrm{j}_{\mathrm{a}}=\zeta_{\mathrm{a}} \mathrm{j}_{\mathrm{a}}{ }^{\mathrm{ref}}([A] /[A])^{\gamma_{\mathrm{a}}}\left(\mathrm{e}^{\mathrm{a}_{\mathrm{a}} \mathrm{F} \eta_{\mathrm{a}} / \mathrm{RT}}-\mathrm{e}^{-\mathrm{a}_{\mathrm{a}} \mathrm{F} \eta_{\mathrm{a}}} / \mathrm{RT}\right)$

$\mathrm{j}_{\mathrm{c}}=\zeta_{\mathrm{c}} \mathrm{j}_{\mathrm{c}}{ }^{\mathrm{ref}}([C] /[C]) \gamma_{\mathrm{c}}\left(\mathrm{e}^{\mathrm{a}_{\mathrm{c}} \mathrm{F} \eta_{\mathrm{c}} / \mathrm{RT}}-\mathrm{e}^{-\mathrm{a}_{\mathrm{c}} \mathrm{F} \eta_{\mathrm{c}} / \mathrm{RT}}\right)$

Herbir tabaka için çözülen denklemler ve kaynak terimleri Tablo 4'de verilmiştir. Burada yer kısıtlamasından dolayı bütün denklemler verilememiştir. Denklemlerin detaylı hali [11]'den görülebilir.

\section{SONUÇLAR VE TARTIŞMA (RESULTS AND DISCUSSION)}

Yakıt pillerinde bipolar plakanın bir yüzeyi hücrenin anot tabakası iken diğer taraf katot katmanıdır. Her iki yüzey yakıt ve oksidant için akış kanallarına sahiptir. Bu kanallar sayesinde yakıt ve oksidant aktif alanda eşit olarak dağıtılmaya çalışılır. Bu homojen dağılım hücre performansını ve verimini arttırır. Bipolar plakalar, oksijenin ve yakıtın aktif bölgelere dağılımını sağlamakla, ısının aktif alanlardan uzaklaştırılmasıyla, hücreden hücreye akımın iletilmesiyle ve reaktantların yakıt pili sistemindeki sızıntısının önlenmesinden sorumludur [10].

Bipolar plakanın yüzeyinde reaktant gazların yakıt pili içerisinde dağıtımı için gaz akış kanalları vardır. Kanal geometrisi, kullanılan kanal deseni anot ve katot tarafı için farklı olabilir. Ayrıca reaktantların yakıt pili sisteminde akış yönü isteğe göre eş veya zıt olabilir. Bipolar plaka gaz akış kanalı deseninin seçimi ve optimizasyonu, yakıt pilinin performansını büyük ölçüde etkiler. Temel geometri seçimine ek olarak, kanallar arasındaki kanal boyutları ve akış kanal deseni dikkatle düşünülmelidir. Aksi takdirde, rastgele seçimler beklenen hücre akımının ve performansının istenen değerlere ulaşmasını engeller [7].

Yapılan çalışmada tek hücreli ve iki hücreli aynı kütle debisi ve çalışma parametrelerine sahip iki adet PEM yakıt pili analizi ANSYS FLUENT üzerinden gerçekleştirilmiş̧ir. Analiz sonucuna göre tek hücre ve iki hücreli yakıt pili yığını için elde edilen akım yoğunluğu değerleri kullanılarak polarizasyon eğrileri çizilmiştir (Şekil 2).

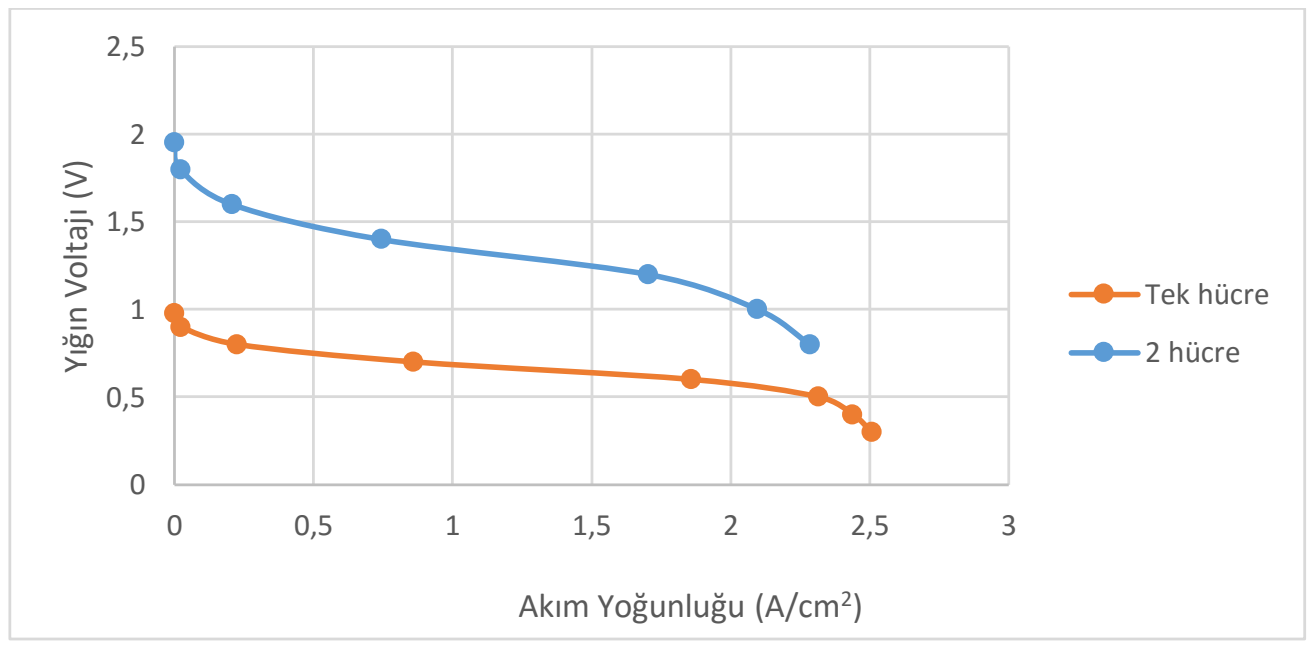

Şekil 2. Tek Hücreli ve İki Hücreli Yakıt Pilleri İçin Polarizasyon Eğrileri 
Tablo 4. PEM Yakit hücresi tabakalarında çözülen eşitlikler ve kaynak terimleri

\begin{tabular}{|c|c|c|c|c|c|c|}
\hline \multirow[t]{2}{*}{ Nicelik } & \multirow[t]{2}{*}{ Korunum Eşitlikleri } & \multicolumn{5}{|c|}{ Kaynak Terimleri } \\
\hline & & $\begin{array}{l}\text { Akım } \\
\text { Toplama } \\
\text { Plakası }\end{array}$ & Gaz Kanalları & $\begin{array}{l}\text { Gaz Difüzyon } \\
\text { Tabaka }\end{array}$ & Katalizör & Membran \\
\hline Kütle & $\nabla(\rho \vec{u})=S_{m}$ & $S_{m}=0$ & $S_{m}=0$ & $S_{m}=0$ & $S_{m}=0$ & $S_{m}=0$ \\
\hline Momentum & $\frac{1}{\varepsilon^{2}} \nabla(\rho \vec{u} \vec{u})=-\nabla p+\nabla \tau+S_{u}$ & $S_{u}=0$ & $S_{u}=0$ & $S_{u}=-\frac{\mu}{K} \varepsilon^{2} \vec{u}$ & $S_{u}=-\frac{\mu}{K} \varepsilon^{2} \vec{u}$ & $S_{u}=-\frac{\mu}{K} \varepsilon^{2}$ \\
\hline Tür & $\nabla\left(\vec{u} C_{k}\right)=\nabla\left(D_{k}^{e f f} \nabla C_{k}\right)+S_{k}$ & $S_{k}=0$ & $S_{k}=0$ & $S_{k}=0$ & $\begin{array}{l}S_{k}=-\frac{M_{w, k}}{n F} R_{a n}, \quad k=H_{2} \\
S_{k}=-\frac{M_{w, k}}{n F} R_{c a t}, \quad k=O_{2}, H_{2} O\end{array}$ & $S_{k}=0$ \\
\hline $\begin{array}{l}\text { Katı Faz } \\
\text { Potansiyeli }\end{array}$ & $\nabla .\left(\sigma_{s o l} \nabla \phi_{s o l}\right)+S_{\phi, s o l}=0$ & $S_{\phi, s o l}=0$ & $S_{\phi, s o l}=0$ & $S_{\phi, s o l}=0$ & $S_{\phi, s o l}=-R_{a n}, S_{\phi, s o l}=R_{c a t}$ & $S_{\phi, s o l}=0$ \\
\hline $\begin{array}{l}\text { Membran } \\
\text { Potansiyeli }\end{array}$ & $\nabla \cdot\left(\sigma_{\text {mem }} \nabla \phi_{\text {mem }}\right)+S_{\phi, \text { mem }}=0$ & $S_{\phi, \text { mem }}=0$ & $S_{\phi, \text { mem }}=0$ & $S_{\phi, \text { mem }}=0$ & $S_{\phi, \text { mem }}=R_{a n}, S_{\phi, \text { mem }}=-R_{c a t}$ & $S_{\phi, \text { mem }}=0$ \\
\hline Enerji & $\nabla(\vec{u} \rho h)=\nabla\left(k^{e f f} \nabla T\right)+S_{h}$ & $S_{h}=0$ & $S_{h}=0$ & $S_{h}=0$ & $S_{h}=I^{2} R_{\text {ohm }}+h_{\text {reaction }}+\eta R_{\text {an,cat }}+h_{\text {phase }}$ & $S_{h}=0$ \\
\hline
\end{tabular}


Şekil 2'den görüldüğü üzere polarizasyon eğrileri benzerlik göstermektedir. İki yakıt pilinde de azalan voltaj değerine karşılık gelen akım yoğunluğu değeri artmıştır. Bu büyük artışlar ise iki hücreli yakıt hücresi için $1 \mathrm{~V}$ ve tek hücreli yakıt pili için $0.5 \mathrm{~V}$ 'a kadar devam etmiş bu değerlerden sonraki akım yoğunluğundaki artışlar düşmüştür. İki hücreli yakıt pilinde ortalama voltaj değeri 2 katına çıkmış ve elde edilen akım yoğunluğu neredeyse aynı kalmıştır. Ancak iki hücreli yakıt pilinde tek hücreli yakıt piline göre elde edilen akım yoğunluğunda kısmi düşüşler olduğu görülmektedir. Bunun nedeni hücre sayısına bağlı olarak oluşan kayıplardır. Hücre sayısına bağlı olarak kayıplar farklı haller alabilir. Bu kayıplar yığın bağlantısındaki aksaklıklar, sürtünmeden kaynaklı basınç düşüşünün reaktantların ilerlediği geçişler fazla olduğu için artması gibi sebeplerden meydana gelebilir.

Elde edilen bu akım yoğunluğu değerlerinden yola çıkarak Eş.(1) ve Eş.(2) kullanılarak iki PEM yakıt pili içinde üretilen elektriksel güç değerleri sayısal olarak hesaplanmıştır. Bu durumda elektriksel güçler Şekil 3.'te gösterilmiştir.

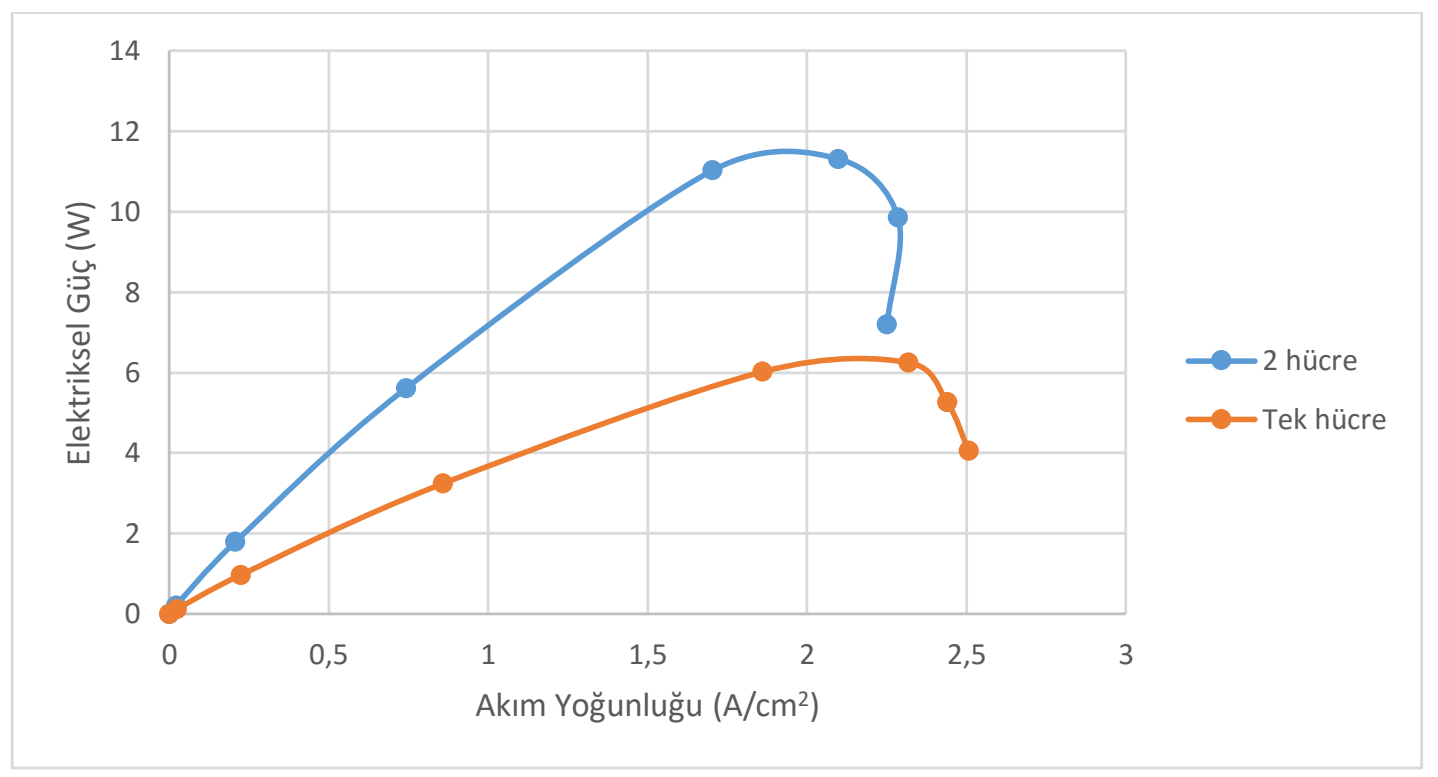

Şekil 3. Tek Hücreli ve İki Hücreli PEM Yakıt Pilleri İ̧̧in Elde Edilen Güç Değerleri

PEM yakıt pilindeki hücre sayısındaki artışa bağlı olarak üretilecek olan elektriksel güç miktarı da arttığ1 Şekil 3’ten görülmektedir. Elektriksel gücün maksimum olmasının ardında gerçekleşen düşüşün tek hücreli yakıt pilinde daha küçük boyutlardayken iki hücreli yakıt pilinde ani bir düşüş gerçekleşmiştir. Hücre sayısı ve bundan kaynaklı voltaj miktarının 2 katına çıkmasına rağmen güç miktarındaki artış bu miktarla doğru orantılı ilerlememektedir. Burada yaklaşık $2 \mathrm{~A} / \mathrm{cm}^{2}$ değerini göz önüne alacak olursak, yakıt pillerinden elde edilen elektriksel gücün bu değere kadar arttığı ve $2 \mathrm{~A} / \mathrm{cm}^{2}$ den sonra düşüşe geçtiği gözlemlenmektedir. İki hücreli ve tek hücreli yakıt pillerinden elde edilen maksimum elektriksel güç değerleri $11.32 \mathrm{~W}$ ve $6.26 \mathrm{~W}$ olarak hesaplanmıştır. Bunun nedeni elde edilen akım yoğunluğundaki düşüştür. Bu da yine hücre sayısına bağlı kayıplardan dolayı ortaya çıkmaktadır. Artan hücre sayısına göre kayıpların artmasının önüne geçebilmek adına kanal tasarımında değişiklikler yaparak basınç kaybı en aza düşürülebilir, çalışma parametreleri en verimli değerlere getirilebilir, yığın montajları gözden geçirilebilir ve böylece kayıp miktarı azalarak verimlilik artırılabilir.

Aşağıda verilen basınç dağılımı, $\mathrm{H}_{2} \mathrm{O}$ dağılımı, sıcaklık ve akım yoğunluğu dağılımına ait şekillerde iki hücre için de elde edilen değerler benzerlik gösterdiği için şekillerde sadece ilk hücrenin dağılımları kullanılmıştır. İki hücreli PEM yakıt pilinin analizi sırasında katot kanalındaki reaktantın basınç değişimi Şekil 4.'te gösterilmiştir. 


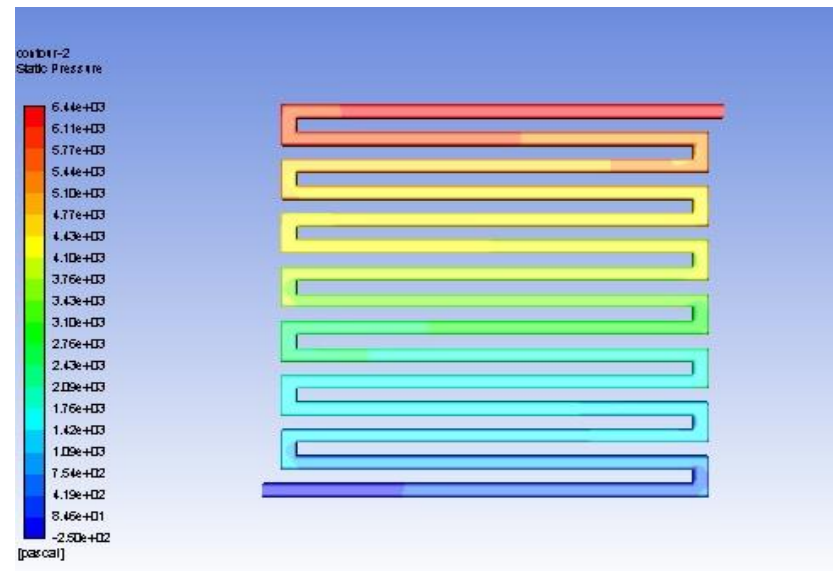

Şekil 4. Katot kanalı basinç değişimi

Şekil 4.'te görüldügü üzere $6.44 \mathrm{e}+03$ Pa basınçla katot kanalına giren akışkan, kanal geometrisi ve sürtünme gibi etkenler yüzünden kademeli olarak azalarak katot kanalı çıkışında 8.46e $+01 \mathrm{~Pa}$ basınca kadar düşmüştür. Anot kanalında ise yaklaşık olarak $300 \mathrm{~Pa}$ değerinde bir basınç düşüşü gözlemlenmiştir. Katot girişine göre anot kanalı debisinin oldukça düşük olması nedeniyle giriş basıncı çok daha düşüktür. Bundan kaynaklı olarak kanal çıkışına kadar gerçekleşen basınç düşüşü de oldukça düşük olmuştur. Yakıt pili çalışmalarında akışın üniform bir şekilde devam etmesi performans açısından oldukça önemlidir. Akışı daha üniform hale getirebilmek için debilerle ve özellikle kanal geometrisi değiştirilebilir.

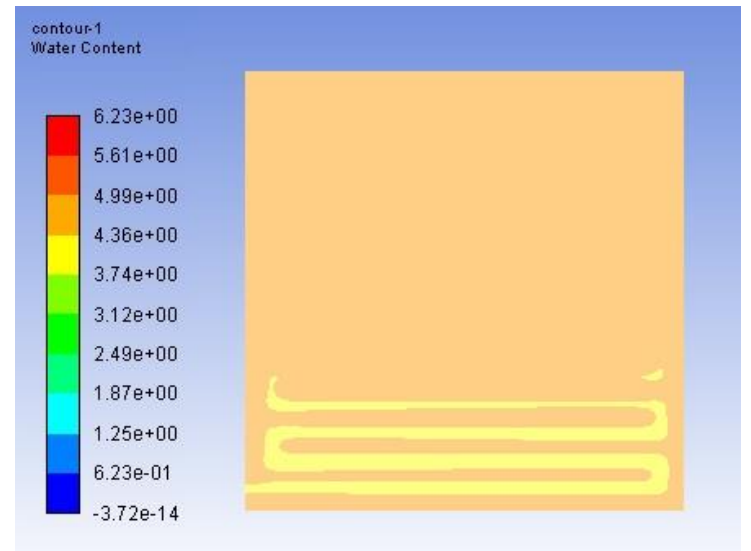

Şekil 5(a). 1.6V'da membrandaki $\mathrm{H}_{2} \mathrm{O}$ dağıllımı dă̆ılımı

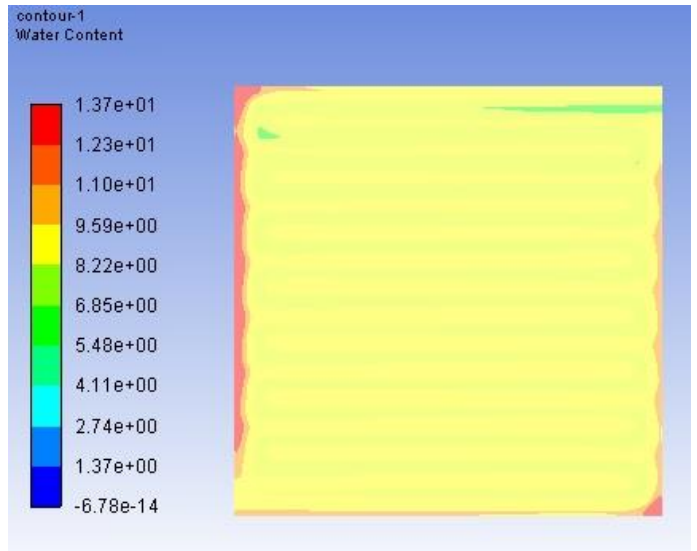

Şekil 5(b). 1.2V'da membrandaki $\mathrm{H}_{2} \mathrm{O}$

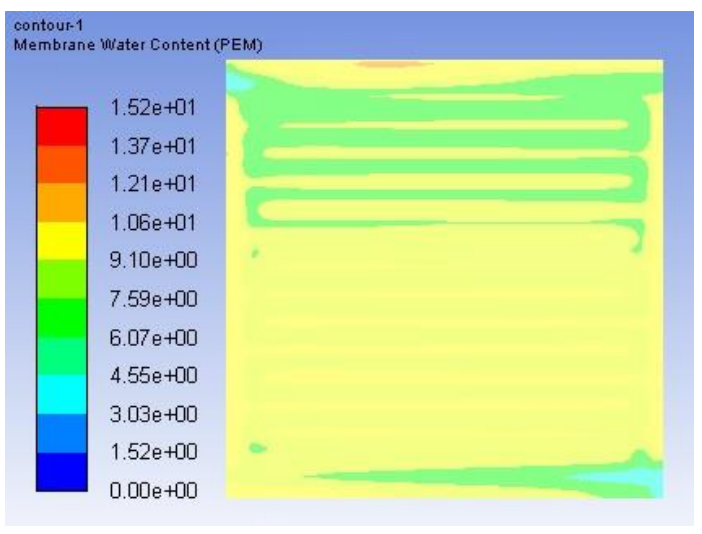

Şekil 5(c). $0.8 V^{\prime}$ da membranda $\mathrm{H}_{2} \mathrm{O}$ dağıllımı

Hücredeki su içeriğinin homojen dağılımının yakıt pili dayanıklılığını olumlu yönde etkilediği bilinmektedir. Katot tarafındaki su taşkını problemi, akış kanalı tasarımı ile üstesinden gelmeye çalışılan ana problemlerden biridir [12]. 
Su buharı ve sıvı suyun $25^{\circ} \mathrm{C}^{\prime}$ ki doygunluğu, sayısal analiz sonuçlarından elde edilen membran su içeriği değeri, eğer 14'e eşit ise birbiriyle denge halindedir. Bu değer 14'ü aşarsa su taşkınına neden olabilir. Yakıt pilinin su taşkınına maruz kalmasını önlemek için su içeriği değerini 14'ün altında tutulması önerilir [13].

Şekil 5.(a), (b) ve (c)'ye bakıldığında en homojen dağılımların yüksek voltaj değerlerinde sağlandığı görülmektedir. $0.8 \mathrm{~V}$ değerinde homojen olmayan bir dağ 11 m gözlemlenmektedir. $\mathrm{Bu}$ durum membran yüzeyinde kuru bölgeler olduğunu gösterir ve bu da yakıt pili performansını olumsuz yönde etkiler. Yine şekillerden yola çıkarak voltaj artımına bağlı olarak su dağılımının da ideal değer olan 14 değerine yaklaştığını söylemek mümkündür. Ancak Şekil 5.(a) ve (b)'ye bakarak bu artışın belirli bir voltaj değerinden sonra tekrar düşüp homojenliğin dağılacağı söylenebilir. Ancak yukarıdaki üç voltaj değeri için de herhangi bir su taşkını gerçekleşmemiştir.

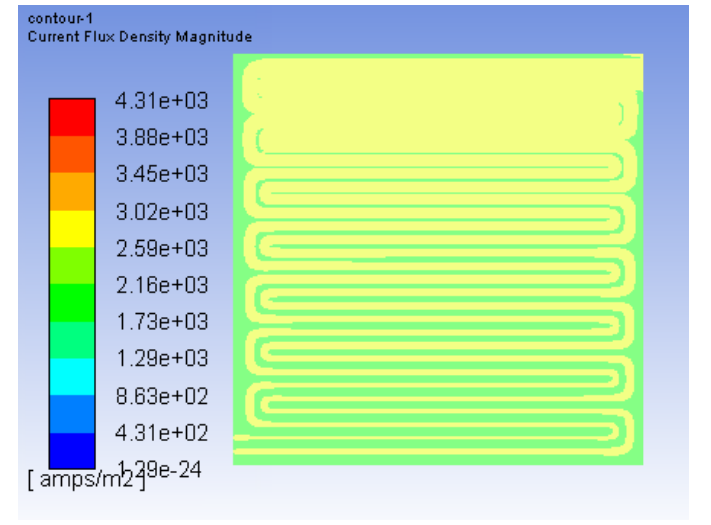

Şekil 6(a). 1.6V için akım yoğunluğu dă̆ılımı

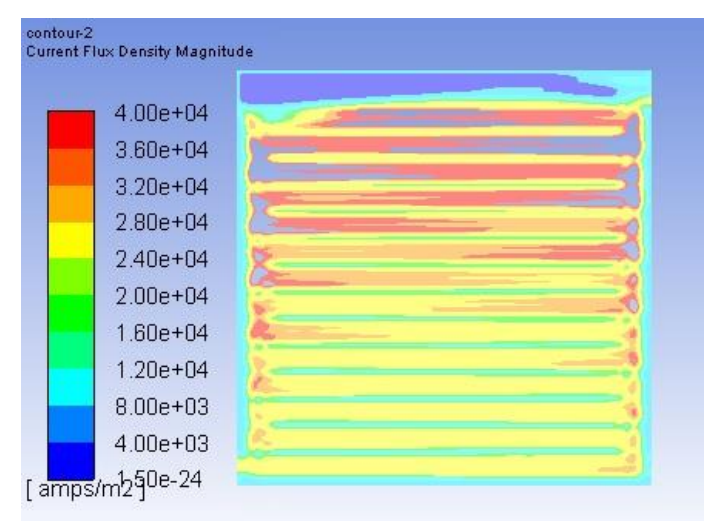

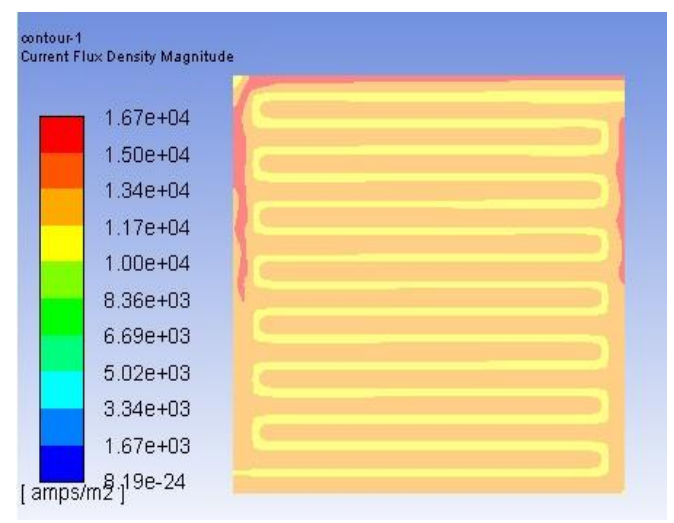

Şekil 6(b). 1.2V için akım yoğunluğu dă̆ılımı

\section{Şekil 6(c). 0.8V için akım yoğunluğu dăğlımı}

Akım yoğunluğunda da su dağılımında olduğu gibi voltaj değerinin azalmasıyla homojenlik de azalmıştır ve düzensiz bir dağılım gözlenmektedir. Yine yukarıdaki sonuçlara bakılarak voltaj değerinin düşmesiyle birlikte akım yoğunluğunda bir artışın olduğu söylenebilir. $1.6 \mathrm{~V}$ ve $0.8 \mathrm{~V}$ değerlerinde kanallarda akım yoğunluğu fazla olurken akış olmayan kollektörün gaz difüzyon katmanıyla temas eden bölgelerinde akım yoğunluğunun düşük olduğu gözlenmiştir. Ancak $1.2 \mathrm{~V}$ değerinde ise bu durum tam tersine dönmüştür ve en homojen dağılım bu voltaj değerinde elde edilmiştir.

Yakıt pilinin performansını iyileştirmek için çalışma sıcaklığı belli bir seviyeye kadar yükseltilebilir. Yakıt pillerindeki sıcaklı̆̆ın arttırılması ile katalizör aktivitesi, elektrokimyasal reaksiyon hızı ve yakıt pilinin membran protonik direnci azalır, böylelikle yakıt pili performansı artar [14]. PEM yakıt pilinde sicaklık dağılımı hücre boyunca aynı olmayabilir. İçeriden dışarıya, girişten çıkışa değişebilir. Bu homojen olmayan sıcaklık dağılımı da yakıt pili performansını düşürebilir [8]. 


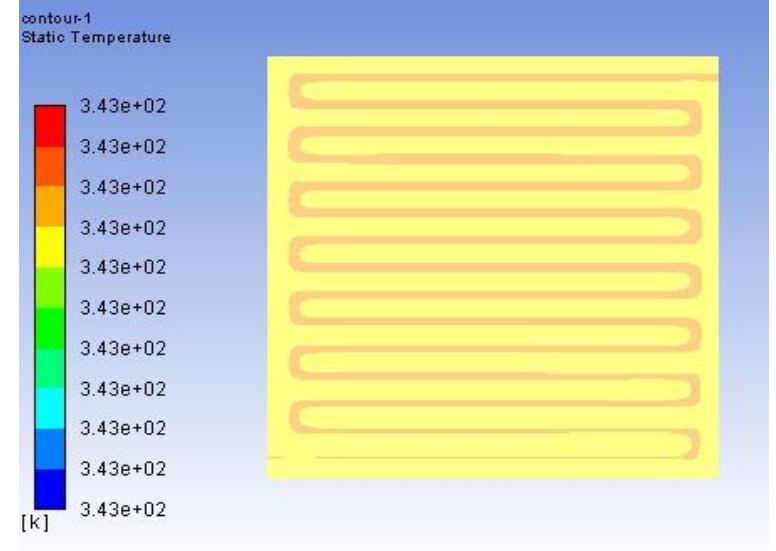

Şekil 7(a). 1.6V için membran sıcaklık dăğllımı

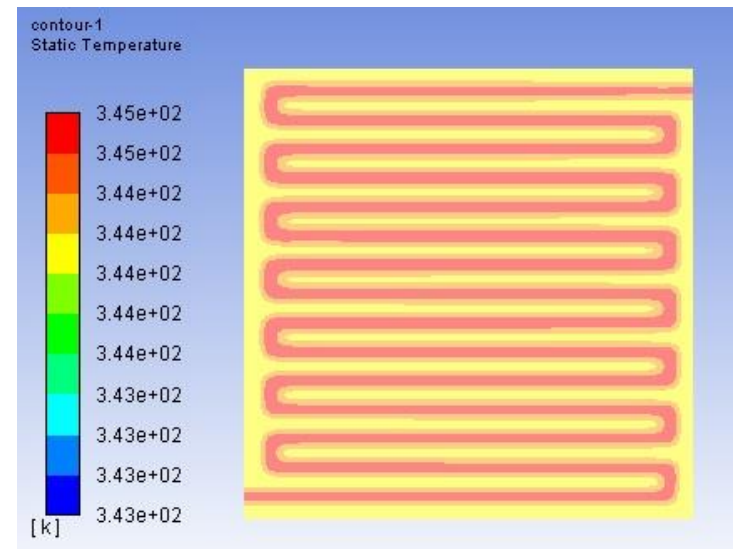

Şekil 7(c). 1.2V için membran sıcaklık dağılımı

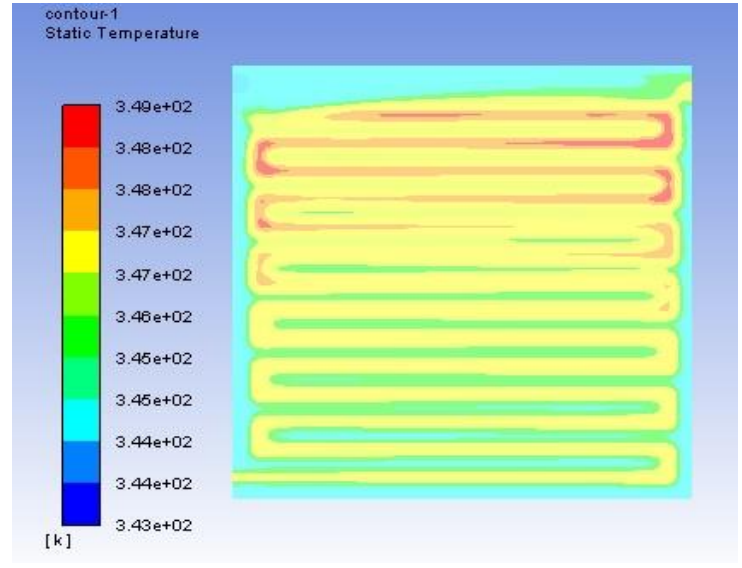

Şekil 7(b). 0.8V için membran sıcaklık dăğlımı

Şekil 7.(a), (b) ve (c)'ye bakıldığında yakıt pilinde çalışma sıcaklığına göre bir sıcaklık artışı hemen hemen hiç olmamaktadır. Ancak sıcaklığın fazla arttığı ve yakıt pili performansını kötü etkileyeceği düşünülen durumlarda yakıt piline soğutma kanalları eklenmelidir. Sonuçlara bakılarak en büyük sıcaklık artışının en küçük voltaj değerinde olup yüksek voltaj değerlerinde sıcaklık değişiminin yok denecek kadar az olduğu $\left(1-2^{\circ} \mathrm{C}\right)$, en homojen sıcaklık dağ 11 ımının en yüksek voltaj değerinde ve en düzensiz dağılımın ise en düşük voltaj değerinde olduğu söylenebilir. Akım kanallarındaki düzensiz sıcaklık dağılımları bölgesel reaksiyonlara ve yakıt pili performansında düşüşlere neden olabilir.

\section{DEĞERLENDİRME (CONCLUSION)}

Bu çalışmada PEM yakıt pillerinden elde edilen gücün hücre sayısına göre değişimi gözlenmiştir. Bunun için tek hücreli ve iki hücreli iki adet PEM yakıt pilinin ANSYS FLUENT ile analizi yapılmıştır. Hücre sayısıyla birlikte elde edilen gücün arttığı ancak hücre sayısıyla beraber kayıpların da artmasından dolayı bu artışın doğru orantılı olmayacağı görülmüş̧ür. Bu kayıplara akışkanın kat ettiği mesafenin artması nedeniyle sürtünme, 1s1 artışı, kanal geometrisinin homojen bir akışa elverişli olmaması veya hücrelerin doğru bir şekilde montaj edilememesi gibi birçok sebepten kaynaklanabilir.

Ayrıca yine bu çalışmada iki hücreli yakıt pili için reaktantların kanallardaki dağılımlarının homojenliği, sıcaklık dağılımı, akım yoğunluğu dağılımı ve suya doygunlukları gibi etmenler, çeşitli voltaj değerleri için analiz edilmiş ve voltaj değerlerine göre bu durumların ne gibi değişikliklere yol açtığı gözlenerek en verimli olan voltaj değerleri belirlenmeye çalışılmıştır. 


\section{KAYNAKLAR (REFERENCES)}

[1] Dyer, C.K. (2002). Fuel cells for portable applications. Journal of Power Sources, 106, 31-40.

[2] Youssef M.E., Amin R.S., El-Khatib K.M. (2018). Development and performance analysis of PEMFC stack based on bipolar plates fabricated employing different designs. Arabian Journal of Chemistry, 11, 609-614.

[3] Xianguo Li, Imran Sabir (2005). Review of bipolar plates in PEM fuel cells: Flow-field designs. Journal of Hydrogen Energy, 30(4), 359-371.

[4] Hontanon E., Escudero M.J., Bautista C., García-Ybarra P.L., Daza L. (2000). Optimisation of flow field in PEM fuel cell using CFD techniques. Journal of Power Sources, 86(1), 363-368.

[5] Sala, P., Stampino, P.G., and Dotelli G. (2014). Design approach for the development of the flow field of bipolar plates for a PEMFC stack prototype. Journal of Fuel Cell Science and Technology, 11, 1-7.

[6] Wu, H. (2009). Mathematical modeling of transient transport phenomena in PEM Fuel Cells. Doktora Tezi, University of Waterloo, Canada, 3-6.

[7] Hoogers, G. (2003). Fuel Cell Technology Handbook. Boca Raton: CRC Press.

[8] Barbir, F. (2005). Introduction. PEM Fuel Cells Theory and Practice, London: Elsevier Academic Press, 207-243.

[9] Lim B.H., Majlan E.H., Daud W.R.W., Rosli M.I., Husaini T., (2019). Three-dimensional study of stack on the performance of the proton exchange membrane fuel cell. Energy, 169, 338-343.

[10] Wu, H. (2009). Mathematical Modeling of Transient Transport Phenomena in PEM Fuel Cells. Doktora Tezi, University of Waterloo, Canada, 3-6.

[11] Bilgili M., Bosomoui M., Tsotridis G. (2015). Gas flow field with obstacle for PEM fuel cells at different operating conditions. International Journal of Hydrogen Energy, 40(5), 2303-2311.

[12] Chen, L., Cao, T., Li, Z., He, Y., and Tao, W. (2012). Numerical investigation of liquid water distribution in the cathode side of proton exchange membrane fuel cell and its effects on cell performance. International Journal of Hydrogen Energy, 37, 9155-9170.

[13] Limjeerajarus, N., \& Charoen-amornkitt, P. (2015). Effect of different flow field designs and number of channels on performance of a small PEFC. International Journal of Hydrogen Energy, 40, 7144-7158.

[14] Zhang, J. (2008). PEM Fuel Cell Electrocatalyst and Catalyst Layers, Fundamentals and Applications, Canada: Springer, $1-50$.

[15] Demirtaş M., Akkoyun N., Akkoyun E., Çetinbaş İ, (2019). Akıllı Şebekelerde Güneş Enerjisi Üretiminin Zamana Bağlı Olasılıksal Tahmini. Gazi Üniversitesi Fen Bilimleri Dergisi Part C: Tasarım ve Teknoloji, 7 (2), 411-424. 